\title{
Humoral and Cellular Responses to SARS-CoV-2 in Convalescent COVID-19 Patients With Multiple Sclerosis
}

Ana Zabalza, MD, Georgina Arrambide, MD, PhD, Paula Tagliani, MD, Simón Cárdenas-Robledo, MD, Susana Otero-Romero, MD, PhD, Juliana Esperalba, MD, PhD, Candela Fernandez-Naval, Jesus Trocoli Campuzano, Mónica Martínez Gallo, MD, PhD, Mireia Castillo, Mercè Bonastre, Mireia Resina Sallés, Jordina Beltran, Pere Carbonell-Mirabent, Marta Rodríguez-Barranco, Samuel López-Maza, MD, Pedro José Melgarejo Otálora, MD, Mariano Ruiz-Ortiz, MD, Agustin Pappolla, MD, Breogán Rodríguez Acevedo, MD, Luciana Midaglia, MD, Angela Vidal-jordana, MD, Alvaro Cobo-Calvo, MD, PhD, Carmen Tur, MD, PhD, Ingrid Galán, MD, Joaquín Castilló, MD, PhD, Jordi Río, MD, PhD, Carmen Espejo, MD, PhD, Manuel Comabella, MD, PhD, Carlos Nos, MD, Jaume Sastre-Garriga, MD, PhD, Mar Tintore, MD, PhD,* and Xavier Montalban, MD, PhD*

Neurol Neuroimmunol Neuroinflamm 2022;9:e1143. doi:10.1212/NXI.0000000000001143

\section{Abstract}

\section{Background and Objectives}

Information about humoral and cellular responses to severe acute respiratory syndrome coronavirus 2 (SARS-CoV-2) and antibody persistence in convalescent (COVID-19) patients with multiple sclerosis (PwMS) is scarce. The objectives of this study were to investigate factors influencing humoral and cellular responses to SARS-CoV-2 and its persistence in convalescent COVID-19 PwMS.

\section{Methods}

This is a retrospective study of confirmed COVID-19 convalescent PwMS identified between February 2020 and May 2021 by SARS-CoV-2 antibody testing. We examined relationships between demographics, MS characteristics, disease-modifying therapy (DMT), and humoral (immunoglobulin $\mathrm{G}$ against spike and nucleocapsid proteins) and cellular (interferon-gamma $[\mathrm{IFN}-\gamma]$ ) responses to SARS-CoV-2.

\section{Results}

A total of 121 (83.45\%) of 145 PwMS were seropositive, and 25/42 (59.5\%) presented a cellular response up to 13.1 months after COVID-19. Anti-CD20-treated patients had lower antibody titers than those under other DMTs $(p<0.001)$, but severe COVID-19 and a longer time from last infusion increased the likelihood of producing a humoral response. IFN- $\gamma$ levels did not differ among DMT. Five of 7 (71.4\%) anti--CD20-treated seronegative patients had a cellular response. The humoral response persisted for more than 6 months in $41 / 56(81.13 \%)$ PwMS. In multivariate analysis, seropositivity decreased due to anti-CD20 therapy (OR 0.08 [95\% CI 0.01-0.55]) and increased in males (OR 3.59 [1.02-12.68]), whereas the cellular response decreased in those with progressive disease (OR 0.04 [0.001-0.88]). No factors were associated with antibody persistence.

\author{
Correspondence \\ Dr. Zabalza \\ azabalza@cem-cat.org
}

\section{MORE ONLINE}

COVID-19 Resources

For the latest articles, invited commentaries, and blogs from physicians around the world NPub.org/COVID19

\footnotetext{
*These authors contributed equally to this work (co-senior authors).

From the Servei de Neurologia-Neuroimmunologia (A.Z., G.A., P.T., S.C.-R., S.O.-R., M. Castillo, M.B., M.R.S., J.B., P.C.-M., M.R.-B., S.L.-M., A.P., B.R.A., L.M., A.V.-J., A.C.-C., C.T., I.G., J.C., J.R., C.E., M. Comabella, C.N., J.S.-G., M.T., X.M.), and Preventive Medicine and Epidemiology Department (S.O.-R.), Centre d'Esclerosi Múltiple de Catalunya (Cemcat), Vall d'Hebron Institut de Recerca, Hospital Universitari Vall d'Hebron, Departament de Medicina, Universitat Autònoma de Barcelona; Microbiology Department (J.E., C.F.-N., J.T.C.), Vall d'Hebron University Hospital, Vall d'Hebron Barcelona Hospital Campus, Universitat Autònoma de Barcelona; Immunology Division (M.M.G.), Hospital Universitari Vall d'Hebron and Diagnostic Immunology Research Group, Vall d'Hebron Research Institute (VHIR), Barcelona; Department of Neurology (P.J.M.O.), Hospital General Universitario Gregorio Marañón, Madrid; and Department of Neurology (M.R.-O.), Hospital Universitario 12 de Octubre, Madrid, Spain.
}

Go to Neurology.org/NN for full disclosures. Funding information is provided at the end of the article.

The Article Processing Charge was funded by the authors.

This is an open access article distributed under the terms of the Creative Commons Attribution-NonCommercial-NoDerivatives License 4.0 (CC BY-NC-ND), which permits downloading and sharing the work provided it is properly cited. The work cannot be changed in any way or used commercially without permission from the journal. 


\section{Glossary}

CIS = clinically isolated syndrome; CLIA = chemiluminescence immunoassay; COVID-19 = coronavirus disease 2019; DMT = disease-modifying therapy; EDSS = Expanded Disability Status Scale; IFN = interferon; Ig = immunoglobulin; IGRA = interferon-gamma release immunoassay; $\mathbf{I Q R}$ = interquartile range; $\mathbf{M S}=$ multiple sclerosis; PwMS = patients with MS; RRMS = relapsing-remitting MS; RT-PCR = reverse transcription-PCR; SARS-CoV-2 = severe acute respiratory syndrome coronavirus 2 .

\section{Discussion}

Humoral and cellular responses to SARS-CoV-2 are present in COVID-19 convalescent PwMS up to 13.10 months after COVID-19. The humoral response decreases under anti-CD20 treatment, although the cellular response can be detected in anti-CD20-treated patients, even in the absence of antibodies.

Coronavirus disease 2019 (COVID-19) is a pandemic infection caused by severe acute respiratory syndrome coronavirus 2 (SARS-CoV-2) and has caused almost 5 million deaths worldwide. ${ }^{1}$ Although patients with multiple sclerosis (MS) do not have an increased risk of COVID-19 compared with the general population, risk factors for severe COVID-19 in patients with MS include older age, male sex, comorbidities, progressive forms, and higher disability. ${ }^{2-5}$ In relation to disease-modifying therapy (DMT), only anti-CD20 therapies appear to increase the risk of COVID-19 severity, and interferon (IFN) may play a protective role. ${ }^{2-4}$

Emerging evidence shows that DMTs alter immunologic responses to both SARS-CoV-2 infection and vaccination against the disease. Some DMTs may induce immunomodulation, whereas others deplete T cells, B cells, or both. In this regard, some studies have shown a decreased humoral response to SARS-CoV-2 infection in patients treated with anti-CD20 therapies. ${ }^{6-9}$ For SARS-CoV-2 vaccines, recent studies demonstrate that the humoral response is blunted not only in patients on anti-CD20 therapies but also in those on anti-SP1 receptor treatment. ${ }^{10,11}$ Encouragingly, vaccinated patients with MS on anti-CD20 therapies seem to present a specific cellular response, even in the absence of a humoral response. ${ }^{12,13}$ However, whether these treatments may affect cellular or long-term humoral responses against SARS-CoV-2 natural infection is still unknown. Therefore, the aims of this study were to investigate humoral and cellular responses to SARS-CoV-2 in COVID-19 convalescent patients with MS (PwMS), to identify factors for developing humoral and cellular responses, and to evaluate factors for humoral response persistence.

\section{Methods}

This is a retrospective study involving a cohort of PwMS conducted at the Multiple Sclerosis Centre of Catalonia (Cemcat) in Barcelona between February 1, 2020, and May 22, 2021.

\section{Study Population}

We included PwMS with all of the following criteria: older than 18 years, not vaccinated against SARS-CoV-2, COVID-19 convalescence, and a serologic study performed at any time point during the observation period. Following the European Centre for Disease Prevention and Control guidelines, ${ }^{14}$ COVID-19-confirmed cases were defined as a positive SARSCoV-2 reverse transcription-PCR (RT-PCR) or a positive antibody test. Data were collected using a REDCap-based electronic case report form.

\section{Demographic and Clinical Data}

Demographic, clinical, laboratory, and COVID-19 data were retrieved from hospital electronic health records. Demographic data included age, sex, and ethnicity. Clinical data included comorbidities (obesity, lung disease, cardiovascular disease, diabetes, hypertension, hematologic disease, chronic kidney disease, liver disease, other autoimmune disease, HIV, or malignancy), MS phenotype (clinically isolated syndrome [CIS], relapsing-remitting MS [RRMS], secondary progressive MS, and primary progressive MS), MS disease duration, Expanded Disability Status Scale (EDSS), DMT at the time of COVID-19, treatment duration, and, for patients on anti-CD20 therapy, cladribine, or alemtuzumab, time since last administration. The absolute lymphocyte count $\left(\mathrm{cell} / \mathrm{m}^{3}\right)$ was retrieved for all patients. In anti-CD20-treated patients, immunoglobulins (IgM, IgG, and IgA; mg/dL) and flow cytometry lymphocyte phenotypes (total lymphocytes: $\mathrm{CD}^{+}, \mathrm{CD} 4 \mathrm{~T}$ cells: $\mathrm{CD} 4^{+}, \mathrm{CD} 8 \mathrm{~T}$ cells: $\mathrm{CD} 8^{+}, \mathrm{B}$ cells: $\mathrm{CD} 19^{+}$) were also collected. COVID-19 data included the presence or absence of symptoms and SARS-CoV-2 RT-PCR. COVID-19 severity was categorized as mild-moderate disease or severe-critical disease, as previously described. ${ }^{6}$

\section{Humoral and Cellular Response Studies}

Humoral and cellular responses were analyzed in the clinical microbiology and immunology laboratories of Vall d'Hebron's hospital. The qualitative humoral response was analyzed using different commercial chemiluminescence immunoassays (CLIAs) targeting specific SARS-CoV-2 antibodies against spike and nucleocapsid, as per clinical practice. Qualitative and quantitative CLIA studies were performed in a group of selected patients: SARS-CoV-2 antibodies (IgG, $\operatorname{IgM}$, and $\operatorname{IgA})$ against the nucleocapsid protein $(\mathrm{Ig}-\mathrm{N})$ were 
detected by the Elecsys Anti-SARS-CoV-2 test (Roche Diagnostics, Mannheim, Germany) with a cutoff of 1.0 index performed using a Cobas 8800 system autoanalyzer (Roche Diagnostics, Basel, Switzerland); IgG antibodies against the spike protein (IgG-S) were measured by the LIAISON TrimericS IgG SARS-CoV-2 IgG test (DiaSorin, Stillwater, MN) with a cutoff point of $13.0 \mathrm{AU} / \mathrm{mL}$ performed using an XL Analyzer (DiaSorin, Saluggia, Italy).

The cellular response was assessed in a group of selected patients according to DMT with consecutive sampling, prioritizing those on anti-CD20 therapy. The cellular response was assessed using IFN- $\gamma$ release immunoassay (IGRA) methodology with 2 QuantiFERON SARS-CoV-2 RUO tubes from Qiagen (Hilden, Germany), proprietary mixes of SARS-CoV-2 S protein (Ag1 and Ag2) selected to activate both CD4 and CD8 T cells, as per the manufacturer's instructions. IFN- $\gamma(\mathrm{IU} / \mathrm{mL})$ was measured in these plasma samples using ELISA (QuantiFERON-TB Gold Plus; Qiagen) tests. According to the manufacturers, a test was considered positive if IFN- $\gamma$ was higher than $0.15 \mathrm{IU} / \mathrm{mL}$.

\section{Statistical Analysis}

For the purpose of this study, data capture was locked on May 22, 2021. Descriptive statistics were used to compare demographics and disease characteristics according to classification of the presence or absence of humoral and cellular responses.

Univariable logistic regression models were performed on identified variables to assess their association with the presence of humoral and cellular responses and antibody persistence. Age was treated as a continuous variable, and the EDSS was categorized into 2 bins (EDSS $<3.0$ and $\geq 3.0$ ). DMTs were categorized into 3 categories (untreated, anti-CD20 therapies and other DMTs). The Pearson $\chi^{2}$, Fisher exact test, Student $t$ test, and Mann-Whitney $U$ tests were used for comparisons, as appropriate. ORs with $95 \%$ CIs were estimated using a logistic regression model.

Multivariate logistic regression was applied to determine variables independently associated with presenting a humoral response, a cellular response, and humoral response persistence over 6 months. The model included age, sex, presenting any comorbidity, MS phenotype (CIS/RRMS vs progressive forms), EDSS, DMTs, and COVID-19 severity. Other variables, such as months after COVID-19 of serologic determination or SARS-CoV-2 RT-PCR, were included in the models if considered clinically relevant or if a $p$ value $<0.1$ was obtained by univariate analysis. Disease duration was excluded from the model because collinearity between age and disease duration was detected.

For the purpose of this analysis, seropositive patients were those with positive serologic testing for IgG-S and/or Ig-N at any time point during follow-up. Patients with a cellular response were those with positive results for antigen mix 1 and/or 2.

Humoral response persistence was analyzed only in patients with at least 2 serologic determinations: 1 performed within the first 6 months of COVID-19 diagnosis and another at least 6 months thereafter. The humoral response was considered persistent when serologic determinations were positive both before and after 6 months or when presenting a positive determination after 6 months. Unless otherwise specified, statistical tests were performed at the 0.05 level of significance using Stata version 14.0 (Stata Statistical Software, College Station, TX) and GraphPad Prism version 9.0 (GraphPad Software, San Diego, CA).

\section{Standard Protocol Approvals, Registrations, and Patient Consents}

The study was approved by the ethics committee of Vall d'Hebron University Hospital [EOM(AG)003/2021(5768)]. Patient consent was obtained.

\section{Data Availability}

Anonymized data that support the findings of this study are available on request from the corresponding author. The data are not publicly available due to privacy or ethical restrictions.

\section{Results}

\section{Patient Identification}

Until May 22, 2021, 256 patients with suspected or confirmed COVID-19 were identified in our center. Of those, 243 (94.92\%) had MS; the other 13 had inflammatory-demyelinating diseases of the central and peripheral nervous systems. Of the 243 with MS, 187 had confirmed COVID-19; 56 had clinically suspected COVID-19. Only those with confirmed COVID-19 and at least 1 serologic determination $(\mathrm{n}=145 ; 77.54 \%)$ were included in this study (eFigure 1, links.lww.com/NXI/A693). The distribution of patient DMTs is specified in Table 1. The median follow-up time after COVID-19 of these patients was 10.5 months (interquartile range [IQR] 8.2 months).

\section{SARS-CoV-2 Humoral and Cellular Responses}

One hundred twenty-one (83.44\%) of the 145 PwMS included in the study had a positive serologic determination at some time point. Positive humoral responses were detected at 0-13.10 months after COVID-19 diagnosis. Demographic, clinical, and laboratory characteristics of patients according to positive or negative antibody results are summarized in Table 1. Demographic, MS, and COVID-19 characteristics and previous laboratory findings were similar in those with positive and negative antibodies. SARS-CoV-2 RT-PCR was performed for $106(73.1 \%)$ of the patients, which was positive in $72(59.50 \%)$ seropositive patients and in all seronegative patients. Nineteen (13.1\%) PwMS presented severe or critical COVID-19; 11 (7.6\%) had asymptomatic disease. Patients with severe disease were mostly on anti-CD20 therapies 
Table 1 Clinical and Demographic Characteristics of the Cohort in Relation to SARS-CoV-2 Serostatus

\begin{tabular}{|c|c|c|c|c|c|}
\hline & $\begin{array}{l}\text { Total } \\
(\mathrm{N}=145)\end{array}$ & $\begin{array}{l}\text { Negative } \\
\text { serology }(n=24)\end{array}$ & $\begin{array}{l}\text { Positive } \\
\text { serology }(n=121)\end{array}$ & OR $(95 \% \mathrm{Cl})^{\mathrm{a}}$ & $p$ Value $^{a}$ \\
\hline Age, y, mean (SD) & $46.87(11.25)$ & $46.39(12.90)$ & $46.97(10.97)$ & $1.00(0.97-1.04)$ & 0.817 \\
\hline Male sex, $\mathrm{n}(\%)$ & $52(35.86)$ & $4(16.67)$ & $48(39.67)$ & $3.29(1.03-10.45)$ & 0.032 \\
\hline Any comorbidity, $\mathrm{n}(\%)^{\mathbf{b}}$ & 69 (75.59) & $15(62.50)$ & $54(44.63)$ & $0.48(0.19-1.20)$ & 0.111 \\
\hline Obesity, n (\%) & $27(18.62)$ & $3(12.50)$ & $24(19.83)$ & $1.73(0.47-6.34)$ & 0.401 \\
\hline Progressive MS, $n(\%)^{c}$ & $27(18.62)$ & $9(37.50)$ & $18(14.88)$ & $0.29(0.11-0.78)$ & 0.010 \\
\hline EDSS $\geq 3.0, n(\%)$ & $54(37.24)$ & $13(54.17)$ & $41(33.88)$ & $0.43(0.17-1.07)$ & 0.061 \\
\hline Disease duration, $y$, median (IQR) & $14(11.0)$ & $12.55(11.1)$ & $14.7(11.1)$ & $1.01(0.95-1.06)$ & 0.793 \\
\hline Corticosteroids last $3 \mathrm{mo}, \mathrm{n}(\%)$ & $2(1.38)$ & $1(4.17)$ & $1(0.83)$ & $0.19(0.01-3.25)$ & 0.203 \\
\hline \multicolumn{6}{|l|}{ DMTs, $n$ (\% of the row) } \\
\hline No treatment & $30(20.69)$ & $2(6.67)$ & $28(93.33)$ & Ref & Ref \\
\hline Interferon- $\beta$ & $19(13.10)$ & $3(15.79)$ & $16(84.21)$ & $0.38(0.06-2.63)$ & 0.309 \\
\hline Glatiramer acetate & $13(8.97)$ & 1 (7.69) & $12(92.31)$ & $0.86(0.07-10.69)$ & 0.905 \\
\hline Dimethyl fumarate & $18(12.41)$ & $2(11.11)$ & $16(88.89)$ & $0.57(0.07-4.58)$ & 0.594 \\
\hline Teriflunomide & $12(8.28)$ & - & $12(100.0)$ & - & 0.365 \\
\hline Fingolimod & $6(4.14)$ & - & $6(100.0)$ & - & 0.521 \\
\hline Natalizumab & $4(2.76)$ & - & $4(100.0)$ & - & 0.600 \\
\hline Alemtuzumab & $7(4.83)$ & $2(28.57)$ & $5(71.43)$ & $0.18(0.02-1.79)$ & 0.097 \\
\hline Cladribine & $2(1.38)$ & - & $2(100.0)$ & - & 0.711 \\
\hline Ocrelizumab & $7(4.83)$ & $2(28.57)$ & $5(71.43)$ & $0.18(0.18-1.78)$ & 0.097 \\
\hline Rituximab & $22(15.17)$ & $10(45.45)$ & $12(54.55)$ & $0.086(0.01-0.56)$ & 0.001 \\
\hline Other anti-CD20 & $4(2.76)$ & $2(50.0)$ & $2(50.0)$ & $0.07(0.00-1.10)$ & 0.013 \\
\hline Other DMTs & $1(0.69)$ & - & $1(100.0)$ & - & 0.793 \\
\hline Anti-CD20 & $33(22.76)$ & $14(42.42)$ & 19 (57.58) & $0.13(0.05-0.37)$ & 0.000 \\
\hline Treatment duration, $y$, median (IQR) & $2.7(4.9)$ & $1.85(3.0)$ & $3.0(5.0)$ & $1.04(0.94-1.16)$ & 0.405 \\
\hline $\begin{array}{l}\text { Time of COVID-19 since last infusion, } \\
\text { mo, median (IQR) }\end{array}$ & $4.0(5.2)$ & $3.15(5.10)$ & $5.0(8.7)$ & $1.08(0.96-1.22)$ & 0.203 \\
\hline $\begin{array}{l}\text { Time of serology since last infusion, } \\
\text { mo, median (IQR) }\end{array}$ & $4.47(6.83)$ & $5.42(6.64)$ & $4.47(9.36)$ & $1.06(0.96-1.16)$ & 0.269 \\
\hline Previous lymphocyte count, median (IQR) ${ }^{2}$ & $1,700(1,000)$ & $1,400(900)$ & $1,730(1,000)$ & $1.00(0.99-1.00)$ & 0.381 \\
\hline Previous IgG count, median (IQR) ${ }^{3}$ & $914(287)$ & $942.5(338)$ & 869 (317.5) & $1.00(0.99-1.00)$ & 0.440 \\
\hline Previous IgM count, median (IQR) ${ }^{3}$ & $88(50)$ & $78.5(52.5)$ & $90.5(50.5)$ & $1.02(0.98-1.04)$ & 0.264 \\
\hline Previous IgA count, median (IQR) ${ }^{3}$ & $192(109)$ & $182(41)$ & $221(76)$ & $1.01(0.99-1.02)$ & 0.094 \\
\hline Negative RT-PCR, n (\%) & $10(6.90)$ & - & $10(8.26)$ & Ref & Ref \\
\hline Positive RT-PCR, n (\%) & $96(66.21)$ & $24(100.0)$ & $72(59.50)$ & $2.10(0.71-6.21)$ & 0.170 \\
\hline RT-PCR not performed, $n$ (\%) & $39(26.90)$ & - & $39(32.23)$ & $0.83(0.28-2.43)$ & 0.730 \\
\hline COVID-19 symptoms, n (\%) & $134(90.34)$ & $20(83.33)$ & $111(91.74)$ & $2.22(0.63-7.86)$ & 0.205 \\
\hline
\end{tabular}


Table 1 Clinical and Demographic Characteristics of the Cohort in Relation to SARS-CoV-2 Serostatus (continued)

\begin{tabular}{|c|c|c|c|c|c|}
\hline & $\begin{array}{l}\text { Total } \\
(N=145)\end{array}$ & $\begin{array}{l}\text { Negative } \\
\text { serology }(n=24)\end{array}$ & $\begin{array}{l}\text { Positive } \\
\text { serology }(n=121)\end{array}$ & OR $(95 \% \mathrm{CI})^{\mathrm{a}}$ & $p$ Value \\
\hline COVID-19 severe-critical course, $n(\%)^{d}$ & $19(13.10)$ & $3(12.50)$ & $16(13.22)$ & $1.07(0.28-4.01)$ & 0.924 \\
\hline $\begin{array}{l}\text { Time of serologies after COVID-19 diagnosis, } \\
\text { months, mean (IQR) }\end{array}$ & $3.19(2.40)$ & $3.38(4.42)$ & $3.15(2.3)$ & $0.98(0.85-1.12)$ & 0.747 \\
\hline
\end{tabular}

Abbreviations: COVID-19 = coronavirus disease 2019; DMT = disease-modifying therapy; EDSS = Expanded Disability Status Scale; IgG, IgM, IgA = immunoglobulin $\mathrm{G}, \mathrm{M}$, or A; IQR = interquartile range; MS = multiple sclerosis; RT-PCR = reverse transcription-PCR; SARS-CoV-2 = severe acute respiratory syndrome coronavirus 2. Percentage is the proportion of patients of the column with that variable if not otherwise specified. Bold indicates statistically significant $p$ value $<0.05$. Count of total cases of variables with missing information: $n^{1}=73, n^{2}=129$, and $n^{3}=28$.

a Statistical analysis was performed using a not adjusted logistic regression model.

${ }^{\mathrm{b}}$ Any comorbidity includes obesity, lung disease, cardiovascular disease, diabetes, hypertension, hematologic benign disease, chronic kidney disease, liver disease, HIV, or malignancy.

'Progressive MS includes secondary progressive multiple sclerosis and primary progressive multiple sclerosis.

${ }^{d}$ COVID-19 severity is categorized as (1) mild-moderate disease if patients had no signs or symptoms of pneumonia or a mild pneumonia and (2) severe-critical disease if they presented dyspnea, or a respiratory rate of $\geq 30$ breaths per minute or a blood oxygen saturation of $\leq 93 \%$, or a ratio of the partial pressure of arterial oxygen to the fraction of inspired oxygen of $<300 \mathrm{~mm} \mathrm{Hg}$, or infiltrates in $>50 \%$ of the lung field within 24-48 hours from the onset of symptoms and/or organ or multiple organ failure.

(42.1\%) or untreated (47.4\%) (data not shown, eTable 5, links.lww.com/NXI/A693). Multivariable analysis revealed that males were more likely to become seropositive (OR $3.59,95 \%$ CI $1.02-12.68, p<0.05$ ), whereas PwMS under anti-CD20 therapy had a higher risk of remaining seronegative than untreated patients (OR 0.08, 95\% CI 0.01-0.55, $p=0.01$ ) (Figure 1A).

When exploring the 33 patients on anti-CD20 therapy, 19 (57.6\%) had a positive humoral response. In multivariable analysis, only severe COVID-19 infection (OR 14.06, 95\% CI 1.02-192.68, $p=0.048$ ) and a longer time between the last treatment infusion and COVID-19 disease (OR per month $1.51,95 \%$ CI 1.01-2.24, $p=0.042$ ) were significantly associated with a higher probability of developing a humoral response after COVID-19 (eTable 1, links.lww.com/NXI/ A693).

Antibody titers were measured in 124 patients with demographic and MS characteristics similar to those of the total cohort (data not shown). Anti-CD20-treated patients presented lower IgG-S (15.4 [IQR 60.0]) and Ig-N median (0.08 [IQR 0.13]) titers than those on other DMTs (37.8 [IQR 68.3] $p>0.05$, and 19.55 [IQR 42.92], $p<0.001)$ or untreated patients (74.3 [IQR 182.4], $p<$ 0.05 , and 34.3 [IQR 128.8], $p<0.001$ ). Patients on fingolimod presented lower median titers of IgG-S (17.0 [IQR 13.5]) and Ig-N (2.16 [IQR 2.21]) than those on other DMTs, although no significant differences were found due to the small number of cases. A higher proportion of seropositivity according to each DMT was observed for antibodies against nucleocapsid compared with those against spike, especially in patients treated with IFN (61.5\% vs $38.5 \%$ ) (Figure 1, B and C).

In patients treated with anti-CD20 therapy, the number of months since the last infusion of COVID-19 correlated with IgG-S titer $(r=0.50$ [95\% CI 0.13-0.75]; $p<0.01)$. However, no correlation was found with Ig-N antibodies or with antibody titers and treatment duration. In patients treated with cladribine and alemtuzumab, the association of antibody titer with time since last treatment administration or treatment duration could not be analyzed due to the low number of cases (eFigures 2 and 3, links.lww.com/NXI/A693).

The cellular response was analyzed in 42 patients selected according to DMT: 22 on anti-CD20 therapy, 5 without treatment, and 15 on other DMTs. Twenty-five (59.5\%) of these 42 patients presented a cellular response, which was detected 0.6-13.0 months after COVID-19, with a median time of 7.0 months (IQR 7.2 months). No differences were found in demographic and MS variables between positive and negative responders (eTable 2, links.lww.com/NXI/ A693). Nonetheless, all patients with severe COVID-19 presented a cellular response $(p=0.018)$. Five of these patients were on anti-CD20 therapy, 1 was on dimethyl fumarate, and 1 was untreated. In multivariable analysis, the occurrence of a cellular response was decreased with progressive MS forms (OR 0.04, 95\% CI 0.001-0.88, $p<0.05$ ) (Figure 2A).

A cellular response was detected in patients with all types of DMT, except for glatiramer acetate $(\mathrm{n}=0 / 2)$. IFN- $\gamma$ titers against antigen 1 or 2 did not differ between anti-CD20treated patients, untreated patients, or those with other DMTs, although the individual proportions of positive determinations varied among DMTs. However, no significant differences were observed due to the low number of cases per DMT (Figure 2, B and C).

Twenty (47.6\%) of the 42 patients analyzed presented both humoral and cellular responses. In severe cases, the proportion of those with both responses increased up to $85.7 \%$ (6 of 7) (eTable 3, links.lww.com/NXI/A693). In seronegative patients, a cellular response was observed in 5 of 7 (71.4\%) anti-CD20-treated patients and in none of the patients treated with other DMTs or untreated patients. Mean titers of IFN- $\gamma$ in anti-CD20-treated patients were similar between seropositive and seronegative PwMS (IFN- $\gamma$ against Ag.1: 1.4 
A

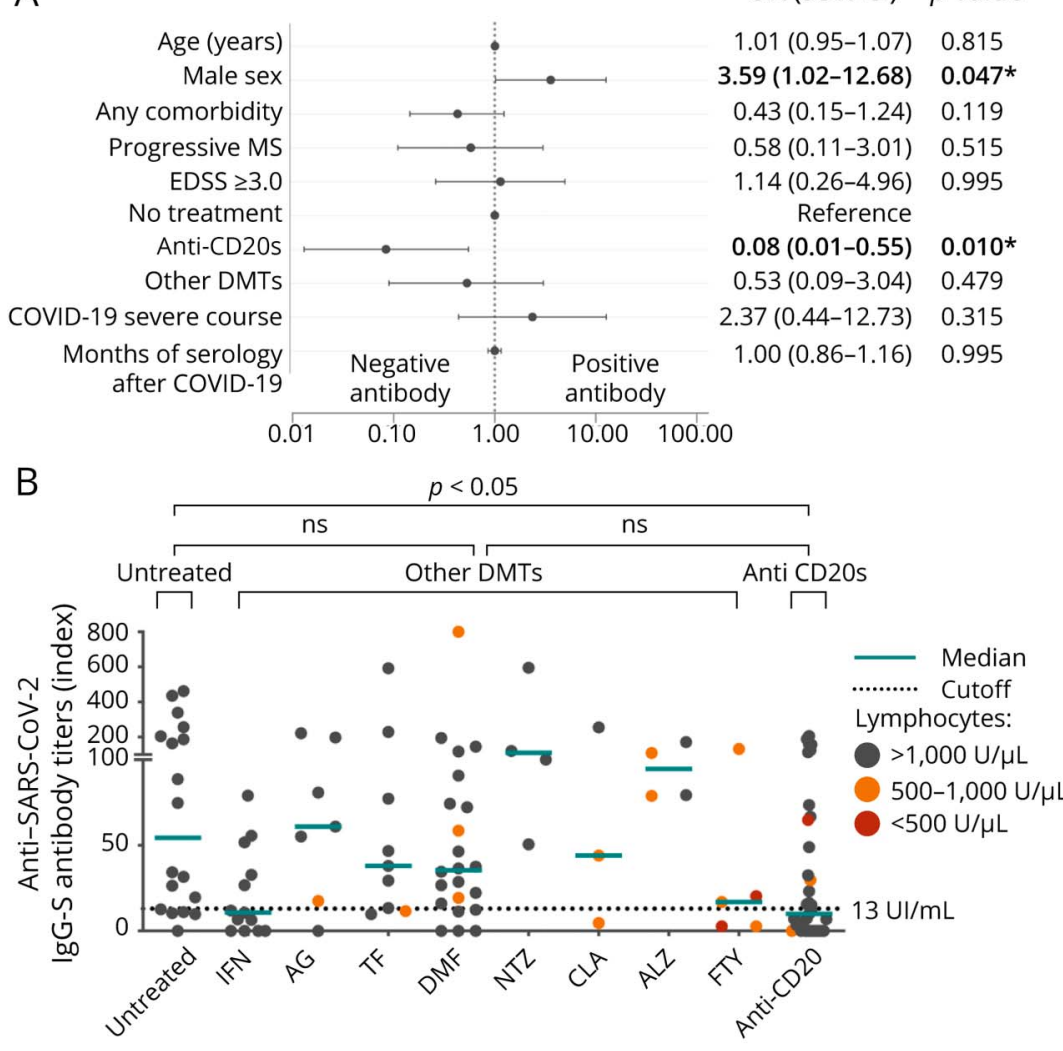

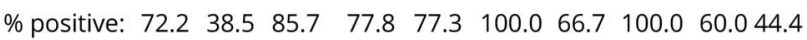

C
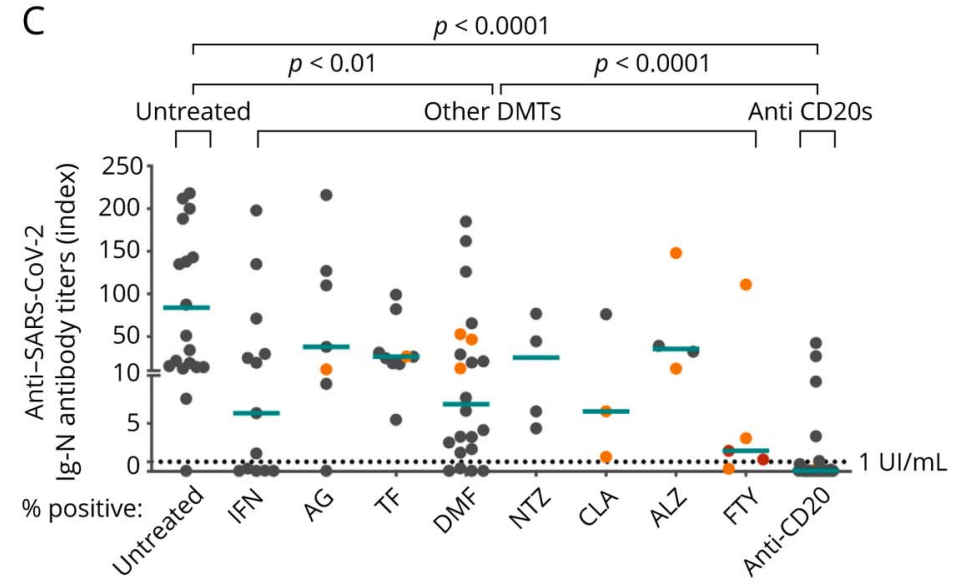

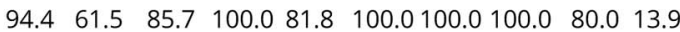

(A) Forest plot depicting adjusted ORs for presenting positive antibodies against SARS-CoV-2 $(n=145)$. Demographic and clinical characteristics, comorbidities, and laboratory data are represented with OR, 95\% CI, and $p$ values. In dichotomous variables, the reference is not specified. Statistical analysis was performed using a logistic regression model adjusted for age, sex presenting any comorbidity, MS phenotype EDSS, DMTs, COVID-19 severity, and months of the serology after COVID-19. (B and C) Median titers of IgG against SARS-CoV-2 spike (IgG-S; A) antibody and total Igs against SARS-CoV-2 nucleocapsid (Ig-N; B), each dot represents a different subject. Statistical analysis was performed using a Mann-Whitney test analysis; only statistically significant differences are indicated. Cutoff values for antibody positivity are indicated by a dotted line. Spot's color indicates previous lymphocyte count $>1,000 \mathrm{U} / \mu \mathrm{L}$ (gray), between 500 and 1,000 $\mathrm{U} / \mu \mathrm{L}$ (orange), and $<500$ cells $/ \mathrm{mm}^{3} \mathrm{U} / \mu \mathrm{L}$. Any comorbidity includes obesity, lung disease, cardiovascular disease, diabetes, hypertension, hematologic benign disease, chronic kidney disease, liver disease, HIV, or malignancy. *Statistically significant, $p$ value $<0.05$. Ab $=$ SARS-CoV-2 antibody; ALZ = alemtuzumab; CLA = cladribine; COVID-19 = coronavirus disease 2019; DMF = dimethyl fumarate; EDSS = Expanded Disability Status Scale; FTY = fingolimod; GA = glatiramer acetate; $I \mathrm{~g}=$ immunoglobulin; IFN = interferon; NTZ = natalizumab; $\mathrm{OCR}=$ ocrelizumab; other anti-CD20 = other anti-CD20 therapies; other DMTs = patients with disease-modifying treatment different from anti-CD20 therapies; progressive MS = secondary progressive MS and primary progressive MS; RTX = rituximab; SARS-CoV- 2 = severe acute respiratory syndrome coronavirus 2; TFN = teriflunomide.
[SD: 2.0] vs 2.4 [SD: 2.8 ]; $p>0.05 ;$ Ag.2: 1.1 [SD: 1.8 ] vs 1.9 [SD: 2.6]; $p>0.05$ ) (Figure 3). In anti-CD20-treated patients, mean titers of IFN- $\gamma$ did not correlate with months since the last infusion or test or treatment duration (eFigures 2 and 3, links.lww.com/NXI/A693).

No correlation was found between antibody titers (Ig-N and IgG-S) and IFN- $\gamma$ titers. Moreover, previous Ig levels, total lymphocyte counts, $\mathrm{CD} 19^{+}$cells, $\mathrm{CD} 4^{+}$cells, or $\mathrm{CD} 8^{+}$cells did not correlate with antibody or IFN $-\gamma$ titers (data not shown).

\section{SARS-CoV-2 Humoral Response Persistence}

To analyze humoral response persistence, a sensitivity analysis was performed in patients with 1 serology result within the first 6 months after COVID-19 and another after 6 months. Fiftythree PwMS were included, with a median follow-up after COVID-19 of 14.2 months (IQR 0.36). Of those PwMS, 41 (81.13\%) were persistently positive or became positive during follow-up. Furthermore, a persistent humoral response to SARS-CoV-2 after more than 12 months after COVID-19 was found in patients treated with anti-CD20 therapy, other DMTs, 
A

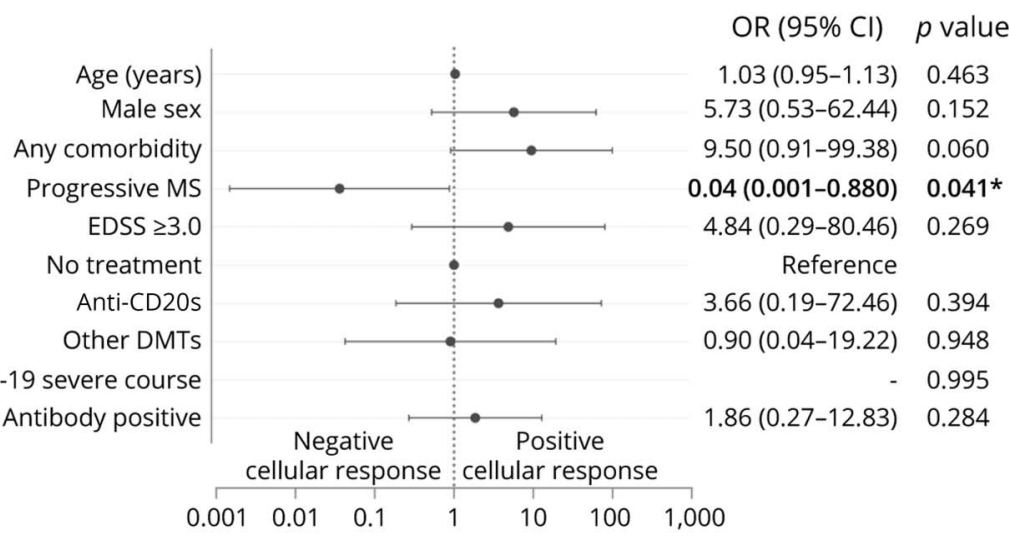

B

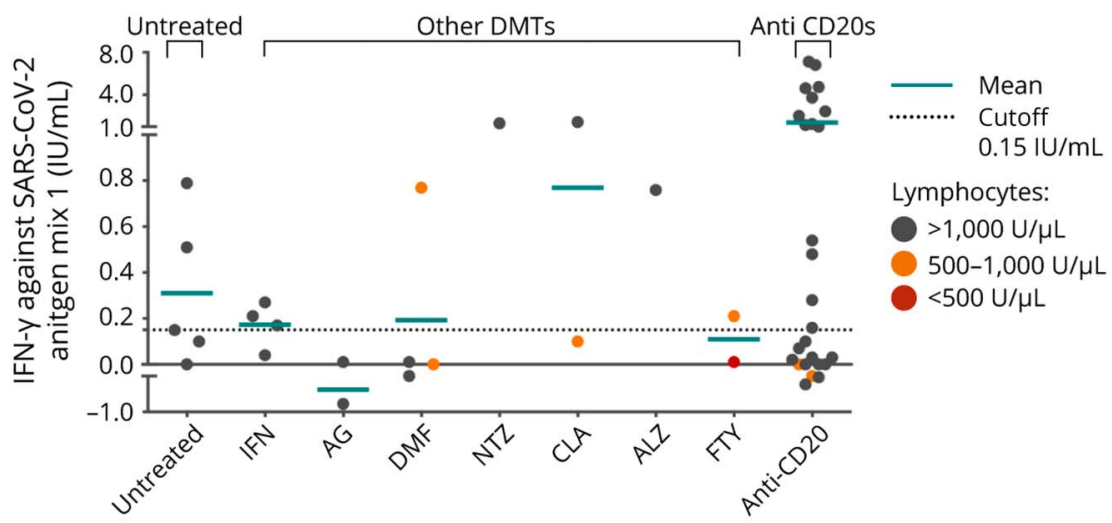

$\begin{array}{llllllllll}\% \text { positive: } & 60.0 & 75.0 & 0 & 25.0 & 100.0 & 50.0 & 100.0 & 50.0 & 66.7\end{array}$

C

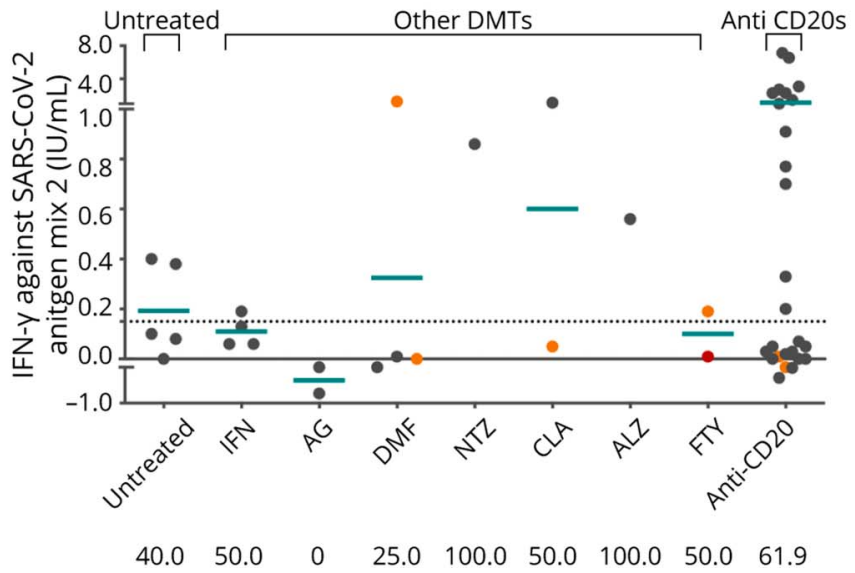

(A) Forest plot depicting adjusted ORs for presenting cellular response against SARS-CoV-2 $(n=42)$ Demographic and clinical characteristics, comorbidities, and laboratory data are represented with $\mathrm{OR}, 95 \% \mathrm{Cl}$, and $p$ values. In dichotomous variables, the reference is not specified. Statistical analysis was performed using a logistic regression model adjusted for age, sex, presenting any comorbidity, MS phenotype EDSS, DMTs, COVID-19 severity, and positive SARS-CoV-2 antibody. (B and C) Mean titers of interferon-gamma produced by T-cell against SARS-CoV-2 antigen mix 1 (A) and SARS-CoV-2 antigen mix 2 (B); each dot represents a different subject. Statistical analysis was performed using a Mann-Whitney test analysis, no statistical differences were found. Cutoff values for positive cellular response are indicated by a dotted line. Values over the lower line of the gray area are considered positive. Spot's color indicates previous lymphocyte count $>1,000 \mathrm{U} / \mu \mathrm{L}$ (gray), between 500 and $1,000 \mathrm{U} / \mu \mathrm{L}$ (orange), and $<500$ cells $/ \mathrm{mm}^{3} \mathrm{U} / \mu \mathrm{L}$. Any comorbidity includes obesity, lung disease, cardiovascular disease, diabetes, hypertension, hematologic benign disease, chronic kidney disease, liver disease, HIV, or malignancy. *Statistically significant, $p$ value $<0.05$. Ab $=$ SARS-CoV-2 antibody; $\mathrm{ALZ}=$ alemtuzumab; CLA = cladribine; COVID-19 = coronavirus disease 2019; DMF = dimethyl fumarate; EDSS = Expanded Disability Status Scale; FTY = fingolimod; $\mathrm{GA}=$ glatiramer acetate; $\mathrm{IFN}=$ interferon; ns = not significant; NTZ = natalizumab; OCR = ocrelizumab; other anti-CD20 = other antiCD20 therapies; other DMTs = patients with disease-modifying treatment different from antiCD20 therapies; progressive MS = secondary progressive MS and primary progressive MS; RTX = rituximab; SARS-CoV-2 = severe acute respiratory syndrome coronavirus $2 ;$ TFN = teriflunomide. and untreated patients. Nevertheless, the percentage of positive serology in anti-CD20-treated patients was lower than that in patients on other DMTs and untreated patients (Figure 4A). In univariable analysis, patients with humoral persistence over 6 months presented a higher median lymphocyte count before COVID-19 than those without persistence (1,715 [IQR 685] vs 1,200 [IQR 100], $p<0.05$ ) (eTable 4, links.lww.com/NXI/ A693). Regardless, no factors were independently associated with humoral response persistence over 6 months in multivariable analysis (Figure 4B).

\section{Discussion}

In this study, we found that humoral and cellular responses to SARS-CoV-2 in convalescent COVID-19 PwMS are present for up to a year after COVID-19 diagnosis and that a cellular response can be present in anti-CD20-treated patients, even in the absence of a humoral response. There are 2 main pillars of an effective antiviral response. One is cellular immunity, specifically T-cytotoxic cells $\left(\mathrm{CD} 8^{+}\right)$, which eliminate infected cells. The other is humoral immunity with plasma cells 

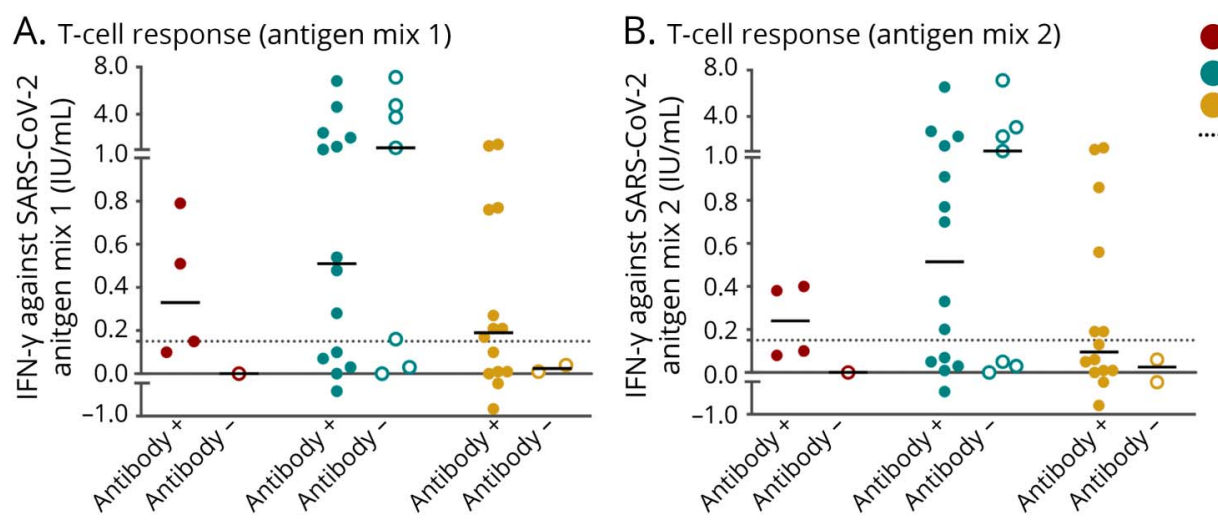

Untreated

Anti-CD20s

Other DMTs

.... Cutoff $0.15 \mathrm{IU} / \mathrm{mL}$

(A and B) Mean IFN-y titers produced by T cells against SARS-CoV-2 antigen mix 1 (A) and antigen mix 2 (B) according to SARS-CoV-2 antibody positivity (Ab+; $\mathrm{Ab}-$ ) and treatment. Each dot represents a different subject. Cutoff values for positive cellular response are indicated by a dotted line. Statistical analysis was performed using a Mann-Whitney test analysis comparing differences between groups and between antibody positive and negative cases, no statistical differences were found. Ab = antibody; other DMTs = patients with disease-modifying treatment different from anti-CD20s therapies; IFN-y = interferongamma; SARS-CoV-2 = severe acute respiratory syndrome coronavirus 2.

that secrete neutralizing antibodies and prevent viruses from infecting cells. After the initial response, $\mathrm{T}$ helper cells coordinate the long-term immune reaction, collaborating in the creation of long-lived plasma cells. ${ }^{15}$

The presence of neutralizing antibodies against SARS-CoV-2 provides the best current indication for protection against reinfection. ${ }^{16}$ We assessed the humoral response to SARS-CoV-2 using a commercially available assay with a demonstrated correlation between $\mathrm{IgG}$ and antibody neutralization titers of $94.4 \%{ }^{17}$ In our cohort, $83.4 \%$ of patients presented antibodies against SARS-CoV-2. In line with previous reports in PwMS, anti-CD20 therapy decreases both the probability of presenting a serologic response and the median titers of antibodies against SARS-CoV$2^{6-9}$ On the other hand, patients treated with other DMTs and untreated patients present an antibody positivity rate of more than $70 \%$. Of interest, we found lower titers of anti-S IgG than Ig$\mathrm{N}$, especially in IFN- $\beta$-treated patients. These differences may be due to the glycosylation state of the spike protein, which makes it less immunogenic. ${ }^{18}$ However, because a recent publication found higher IgG-S antibody titers in convalescent COVID-19 PwMS treated with IFN and glatiramer acetate compared with other DMTs, ${ }^{9}$ our results should be interpreted with caution.

Anti-CD20 therapy affects the B-cell lineage, impairing differentiation into memory B cells or plasma cells. It is not surprising then that PwMS on such treatment fails to develop a humoral response. Among these PwMS, we found a higher humoral response in those with severe COVID-19. ${ }^{19}$ Similarly, the longer it was since SARS-CoV-2 infection after the last anti-CD20 infusion, the higher was the serum anti-S IgG titer and proportion of humoral response positivity. This is probably due to an increasing repopulation of memory $\mathrm{B}$ cells over the months. These results are consistent with previous findings in patients treated with antiCD20 therapy after COVID- $19^{9}$ and after vaccination, ${ }^{20}$ but given our cohort's small sample size, further confirmation is needed.
Lymphodepleting therapies such as cladribine, alemtuzumab, or fingolimod might also modify immunologic responses to SARS-CoV-2 by reducing peripheral B-cell counts. We found an acceptable positive rate among all 3 treatments, as seen in previous studies. ${ }^{8,9}$ Although there is growing evidence showing that the response to SARS-CoV-2 vaccination is blunted in patients on fingolimod, ${ }^{10,11}$ controversy remains regarding the response after COVID-19. ${ }^{8,9,21}$ Similar to other studies, ${ }^{9,21}$ our results suggest that antibody titers are lower in patients on fingolimod than in those on other DMTs. Altogether, confirmation of these data in larger cohorts is needed. Our results also suggest that male sex increases the probability of seroconversion, which is consistent with some of the data published for the general population, in which higher antibody titers were found in male patients. ${ }^{22,23}$

The magnitude and profile of the T-cell response against SARS$\mathrm{CoV}-2$ is heterogeneous and may be a reflection of individual immunologic responses during acute infection. ${ }^{24} \mathrm{We}$ assessed the specific T-cell response using a commercially available IGRA $\mathrm{kit}^{25}$ and found cellular responses in $59.5 \%$ of patients. As previously described in the general population, ${ }^{26,27}$ the cellular response was associated with severe COVID-19 in univariable analysis. In fact, all patients with severe COVID-19 had detectable cellular responses. This suggests an increased immune response with higher viral loads and inflammatory mediators during acute infection. ${ }^{28}$

Nevertheless, we detected a specific cellular response despite the absence of a humoral response in 5 patients given antiCD20 therapy but not in patients on other DMTs. Some studies of SARS-CoV-2 infection and vaccination have already described specific cellular responses in the absence of humoral responses. $^{12,13,29}$ In fact, a study of COVID-19 patients with hematologic cancer treated with rituximab showed that those with a higher proportion of $\mathrm{T}$ cells had a better outcome. ${ }^{30}$ 


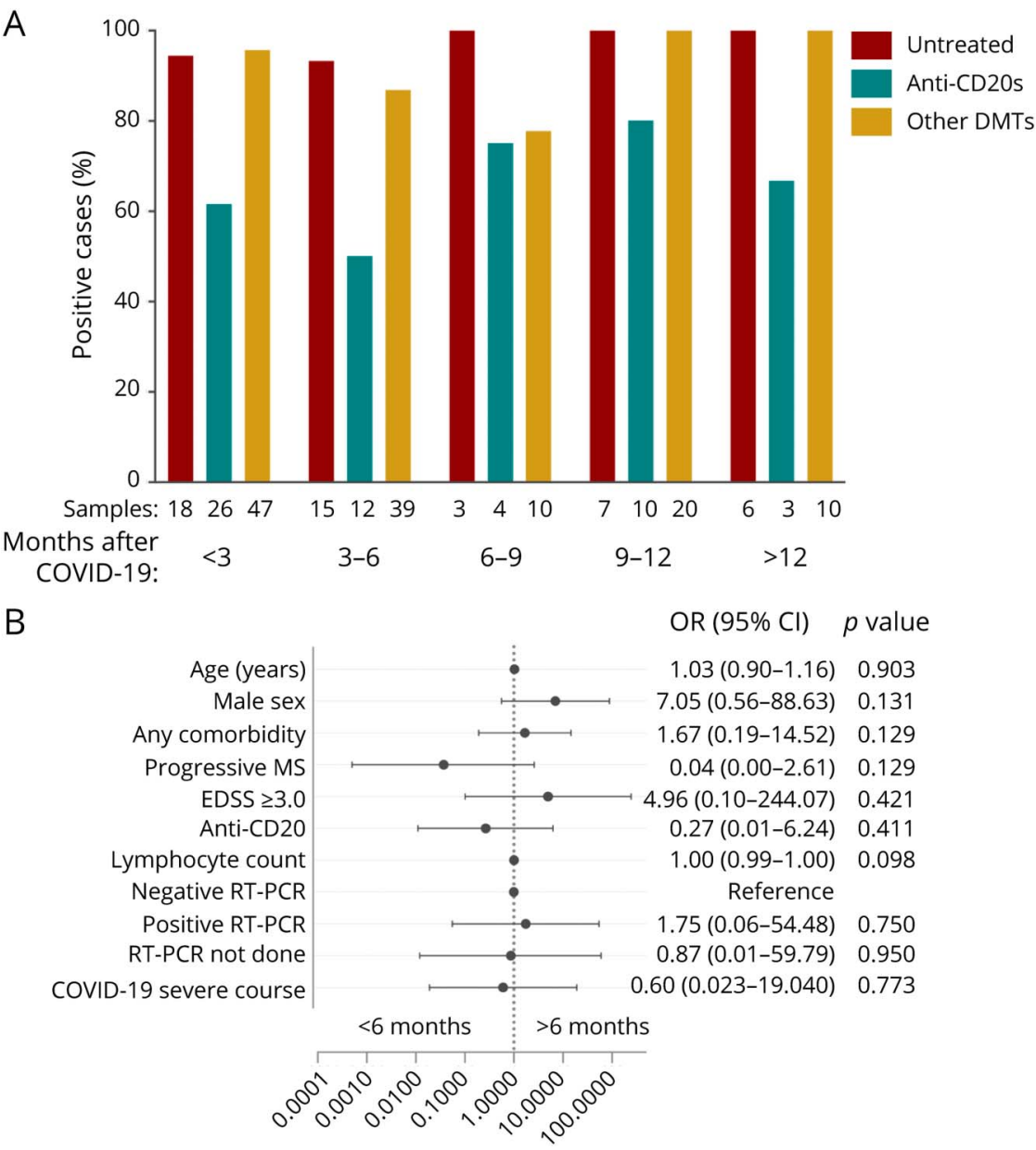

(A) Proportion of positive SARS-CoV-2 serologies according to the months since COVID-19 diagnosis and treatment. (B) Forest plot depicting adjusted ORs for presenting antibody response persistence over 6 months $(n=53)$. Only patients with 2 or more serologic determinations are included. Demographic and clinical characteristics are represented with OR, $95 \% \mathrm{Cl}$ and $p$ values. In dichotomous variables, the reference is not specified. Statistical analysis was performed using a logistic regression model adjusted for age, sex, presenting any comorbidity, MS phenotype EDSS, DMTs, COVID-19 severity, lymphocyte count, and RT-PCR results (not done, negative, or positive). Patient's treatments are classified as untreated, anti-CD20 therapies (rituximab, ocrelizumab, and other anti-CD20s), and other DMTs (interferon, glatiramer acetate, teriflunomide, dimethyl fumarate, cladribine, fingolimod, or alemtuzumab). Any comorbidity includes obesity, lung disease, cardiovascular disease, diabetes, hypertension, hematologic benign disease, chronic kidney disease, liver disease, HIV, or malignancy. COVID-19= coronavirus disease 2019; DMT = disease-modifying therapy; EDSS = Expanded Disability Status Scale; MS = multiple sclerosis; progressive MS = secondary progressive MS and primary progressive MS; RT-PCR = reverse transcription-PCR; SARS-CoV-2 = severe acute respiratory syndrome coronavirus 2 .

Therefore, the cellular response might play an important role in COVID-19 recovery when humoral immunity is impaired.

In our cohort, progressive phenotypes were less likely to present humoral and cellular responses. In both cases, the decreased response might be justified by the older age of these patients or premature immunosenescence associated with progressive forms, ${ }^{31}$ leading to a weakened immune response. However, potential confounders such as anti-CD20 therapy should be ruled out in future analyzes with larger cohorts.

Humoral and cellular responses against SARS-CoV-2 are detected within a few days of COVID-19 onset to up to 12 months. ${ }^{32,33}$ We were able to detect both of them up to 13.10 months after COVID-19 disease. The humoral response persisted for more than 6 months in $81.1 \%$ of patients with 2 determinations. In the general population, increased severity of COVID-19 and younger age have been associated with longer SARS-CoV-2 humoral persistence, ${ }^{34,35}$ although we did not find any association in this regard, probably because of the small cohort. Nonetheless, further information about long-term immunity in PwMS after SARS-CoV-2 vaccination is needed.
Limitations of our study are as follows. During the first wave of the pandemic, RT-PCR testing in our province was restricted to hospitalized patients. Therefore, our cohort's first cases were either severe cases or patients with positive serology performed in the convalescence phase. This might have led to an increased estimation of the positive serologic rate, as there might be an overrepresentation of patients with severe COVID-19 infection. In addition, all tests were performed according to clinical practice and not to established time points after COVID-19 diagnosis, which has led to variability in the time and frequency of testing after COVID-19, increasing the heterogeneity of the sample. Another limitation is the relatively small sample size of the study, probably leading to an overestimation of associations and a high degree of uncertainty. In the cellular response substudy in particular, there were few cases for each DMT, which prevented us from performing group comparisons. Our strengths include the deeply phenotyped cohort with valuable information on previous laboratory data and a long-term follow-up of PwMS and COVID-19. Moreover, to detect the cellular response, we used a commercially available test suitable for clinical laboratories and amenable to automation, making it potentially useful to 
evaluate cellular response after COVID-19 or SARS-CoV-2 vaccination. However, it should be considered that previous studies on the SARS-CoV-2 cellular response in MS have used other methods, such as intracellular cytokine staining or other IGRAs, which may limit the reproducibility of our results.

In conclusion, convalescent COVID-19 patients with MS have preserved specific humoral and cellular responses to SARS-CoV-2 up to 13 months after COVID-19, although the humoral response is reduced in patients on anti-CD20 therapy. Overall, these data provide valuable information about the immune response in convalescent COVID-19 MS patients and can be used for clinical guidance.

\section{Acknowledgment}

The authors thank Dr. Moises Labrador and Dr. Manuel Hernandez from the Immunology service of Vall d'Hebron service for suggesting the IGRA technique and his immunologic support.

\section{Study Funding}

No targeted funding reported.

\section{Disclosure}

A. Zabalza has received travel expenses for scientific meetings from Biogen Idec, Merck Serono, and Novartis, speaking honoraria from Eisai, and a study grant from Novartis. G. Arrambide has received compensation for consulting services or participation in advisory boards from Sanofi, Merck, and Roche, research support from Novartis, travel expenses for scientific meetings from Novartis, Roche, Stendhal, and ECTRIMS, and speaking honoraria from Sanofi and Merck and is a member of the International Women in Multiple Sclerosis (iWiMS) network executive committee. P. Tagliani was an ECTRIMS clinical fellowship awardee in 2019-2020 and has received travel expenses for scientific meetings from Roche. S. Cárdena-Robledo was an ECTRIMS clinical fellowship awardee 2019-2020 and has received travel expenses for scientific meetings from Biogen Idec and Genzyme, compensation for consulting services or participation in advisory boards from Roche and Novartis, and speaking honoraria from Novartis. S. Otero-Robledo has received compensation for consulting services from Biogen Idec and Genzyme and research support from Novartis. J. Esperalba; C. FernandezNaval, J. Trocoli Campuzano, M. Martínez Gallo, M. Castillo, M. Bonastre, M. Resina Sallés, and J. Beltran report no disclosures relevant to the manuscript. P. Carbonell-Mirabent has received travel expenses from Biogen. P.C.-M's yearly salary is supported by a grant from Biogen to Fundació Privada Cemcat toward statistical analysis. M. Rodríguez-Barranco, S. López-Maza, P.J. Melgarejo Otálora, and M. Ruiz-Ortiz report no disclosures relevant to the manuscript. A. Papolla is an ECTRIMS clinical fellowship awardee. B. Rodríguez Acevedo has received honoraria for consulting services from Wellspect. L. Midaglia has received honoraria for consulting services and speaking honoraria from Roche and Novartis. A. Vidal-Jordana has received compensation for consulting services and speaking honoraria from Novartis, Roche, Teva, Mylan, Biogen, and Genzyme-Sanofi. A. CoboCalvo has received grant from Instituto de Salud Carlos III, Spain;
JR19/00007. C. Tur is currently being funded by a Junior Leader La Caixa Fellowship; the fellowship code is LCF/BQ/PI20/ 11760008; she has also received the 2021 Fundación Merck Salud Award for the Investigation in Multiple Sclerosis (Spain); in 2015, she received an ECTRIMS Post-doctoral Research Fellowship and has received funding from the UK MS Society. I. Galán and J. Castilló report no disclosures relevant to the manuscript. J. Río has received speaking honoraria and personal compensation for participating on Advisory Boards from Almirall, Bayer Schering Healthcare, Biogen Idec, and Genzyme. C. Espejo reports no disclosures relevant to the manuscript. M. Comabella has received compensation for consulting services and speaking honoraria from Bayer Schering Pharma, Merck Serono, Biogen Idec, Teva Pharmaceuticals, Sanofi-Aventis, and Novartis. C. Nos has received funding for travel from Biogen Idec and $\mathrm{F}$. Hoffmann-La Roche, Ltd., and speaker honoraria from Novartis. J. Sastre-Garriga has received compensation for consulting services and speaking honoraria from Almirall, Bayer, Biogen, Celgene, Sanofi, Merck, Novartis, Roche, Bial, Biopass, and Teva and is member of the editorial committee of Multiple Sclerosis Journal and director of Revista de Neurología. M. Tintore has received compensation for consulting services and speaking honoraria from Almirall, Bayer Schering Pharma, Biogen Idec, Genzyme, Merck Serono, Novartis, Roche, Sanofi-Aventis Viela Bio, and Teva Pharmaceuticals and is coeditor of Multiple Sclerosis Journal-Experimental, Translational and Clinical. X. Montalban has received speaking honoraria and travel expenses for scientific meetings, has been a steering committee member of clinical trials, or participated in advisory boards of clinical trials in the past 3 years with Actelion, Alexion, Bayer, Biogen, Celgene, EMD Serono, Genzyme, Immunic, MedDay, Merck, Mylan, NervGen, Novartis, Roche, Sanofi-Genzyme, Teva Pharmaceutical, TG Therapeutics, Excemed, MSIF, and NMSS. Go to Neurology. org/NN for full disclosures.

\section{Publication History}

Received by Neurology: Neuroimmunology \& Neuroinflammation August 20, 2021. Accepted in final form December 21, 2021.

\begin{tabular}{|c|c|c|}
\hline Name & Location & Contribution \\
\hline $\begin{array}{l}\text { Ana Zabalza, } \\
\text { MD }\end{array}$ & $\begin{array}{l}\text { Servei de Neurologia- } \\
\text { Neuroimmunologia, Centre } \\
\text { d'Esclerosi Múltiple de } \\
\text { Catalunya (Cemcat), Vall } \\
\text { d'Hebron Institut de Recerca, } \\
\text { Hospital Universitari Vall } \\
\text { d'Hebron, Departament de } \\
\text { Medicina, Universitat } \\
\text { Autònoma de Barcelona, Spain }\end{array}$ & $\begin{array}{l}\text { Drafting/revision of the } \\
\text { manuscript for content, } \\
\text { including medical writing for } \\
\text { content; major role in the } \\
\text { acquisition of data; study } \\
\text { concept or design; and } \\
\text { analysis or interpretation of } \\
\text { data }\end{array}$ \\
\hline $\begin{array}{l}\text { Georgina } \\
\text { Arrambide, } \\
\text { MD, PhD }\end{array}$ & $\begin{array}{l}\text { Servei de Neurologia- } \\
\text { Neuroimmunologia, Centre } \\
\text { d'Esclerosi Múltiple de } \\
\text { Catalunya (Cemcat), Vall } \\
\text { d'Hebron Institut de Recerca, } \\
\text { Hospital Universitari Vall } \\
\text { d'Hebron, Departament de } \\
\text { Medicina, Universitat } \\
\text { Autònoma de Barcelona, Spain }\end{array}$ & $\begin{array}{l}\text { Drafting/revision of the } \\
\text { manuscript for content, } \\
\text { including medical writing for } \\
\text { content; major role in the } \\
\text { acquisition of data; study } \\
\text { concept or design; analysis } \\
\text { or interpretation of data; } \\
\text { and additional } \\
\text { contributions: study } \\
\text { supervision }\end{array}$ \\
\hline
\end{tabular}


Appendix (continued)

\begin{tabular}{|c|c|c|}
\hline Name & Location & Contribution \\
\hline $\begin{array}{l}\text { Paula } \\
\text { Tagliani, MD }\end{array}$ & $\begin{array}{l}\text { Servei de Neurologia- } \\
\text { Neuroimmunologia, Centre } \\
\text { d'Esclerosi Múltiple de } \\
\text { Catalunya (Cemcat), Vall } \\
\text { d'Hebron Institut de Recerca, } \\
\text { Hospital Universitari Vall } \\
\text { d'Hebron, Departament de } \\
\text { Medicina, Universitat } \\
\text { Autònoma de Barcelona, Spain }\end{array}$ & $\begin{array}{l}\text { Drafting/revision of the } \\
\text { manuscript for content, } \\
\text { including medical writing for } \\
\text { content, and major role in } \\
\text { the acquisition of data }\end{array}$ \\
\hline $\begin{array}{l}\text { Simón } \\
\text { Cárdenas- } \\
\text { Robledo, MD }\end{array}$ & $\begin{array}{l}\text { Servei de Neurologia- } \\
\text { Neuroimmunologia, Centre } \\
\text { d'Esclerosi Múltiple de } \\
\text { Catalunya (Cemcat), Vall } \\
\text { d'Hebron Institut de Recerca, } \\
\text { Hospital Universitari Vall } \\
\text { d'Hebron, Departament de } \\
\text { Medicina, Universitat } \\
\text { Autònoma de Barcelona, Spain }\end{array}$ & $\begin{array}{l}\text { Drafting/revision of the } \\
\text { manuscript for content, } \\
\text { including medical writing for } \\
\text { content, and major role in } \\
\text { the acquisition of data }\end{array}$ \\
\hline
\end{tabular}

\begin{tabular}{ll}
\hline Susana & Servei de Neurologia- \\
Otero- & Neuroimmunologia, Centre \\
Romero, MD, & d'Esclerosi Múltiple de \\
PhD & Catalunya (Cemcat), Vall \\
& d'Hebron Institut de Recerca, \\
& Hospital Universitari Vall \\
& d'Hebron, Departament de \\
& Medicina, Universitat \\
& Autònoma de Barcelona, Spain \\
& Microbiology Department, \\
\hline Juliana & Vall d'Hebron University \\
Esperalba, & Hospital, Vall d'Hebron \\
MD, PhD & Barcelona Hospital Campus, \\
& Universitat Autònoma de \\
& Barcelona, Spain
\end{tabular}

Drafting/revision of the manuscript for content, including medical writing for content; study concept or design; and analysis or interpretation of data Medicina, Universitat Microbiology Department, Vall d'Hebron University Barcelona Hospital Campus, Barcelona, Spain

Drafting/revision of the manuscript for content, including medical writing for content; major role in the acquisition of data; study concept or design; analysis or interpretation of data; and additional contributions: contribution of vital reagents/tools/ patients

\begin{tabular}{|c|c|c|}
\hline $\begin{array}{l}\text { Candela } \\
\text { Fernandez- } \\
\text { Naval }\end{array}$ & $\begin{array}{l}\text { Microbiology Department, } \\
\text { Vall d'Hebron University } \\
\text { Hospital, Vall d'Hebron } \\
\text { Barcelona Hospital Campus, } \\
\text { Universitat Autònoma de } \\
\text { Barcelona, Spain }\end{array}$ & $\begin{array}{l}\text { Major role in the acquisition } \\
\text { of data; analysis or } \\
\text { interpretation of data; and } \\
\text { additional contributions: } \\
\text { contribution of vital } \\
\text { reagents/tools/patients }\end{array}$ \\
\hline $\begin{array}{l}\text { Jesus Trocoli } \\
\text { Campuzano }\end{array}$ & $\begin{array}{l}\text { Microbiology Department, } \\
\text { Vall d'Hebron University } \\
\text { Hospital, Vall d'Hebron } \\
\text { Barcelona Hospital Campus, } \\
\text { Universitat Autònoma de } \\
\text { Barcelona, Spain }\end{array}$ & $\begin{array}{l}\text { Major role in the acquisition } \\
\text { of data; analysis or } \\
\text { interpretation of data; and } \\
\text { additional contributions: } \\
\text { contribution of vital } \\
\text { reagents/tools/patients }\end{array}$ \\
\hline $\begin{array}{l}\text { Mónica } \\
\text { Martínez } \\
\text { Gallo, MD, } \\
\text { PhD }\end{array}$ & $\begin{array}{l}\text { Immunology Division, } \\
\text { Hospital Universitari Vall } \\
\text { d'Hebron and Diagnostic } \\
\text { Immunology Research } \\
\text { Group, Vall d'Hebron } \\
\text { Research Institute (VHIR), } \\
\text { Barcelona, Spain }\end{array}$ & $\begin{array}{l}\text { Drafting/revision of the } \\
\text { manuscript for content, } \\
\text { including medical writing for } \\
\text { content; study concept or } \\
\text { design; analysis or } \\
\text { interpretation of data; and } \\
\text { additional contributions: } \\
\text { contribution of vital } \\
\text { reagents/tools/patients }\end{array}$ \\
\hline $\begin{array}{l}\text { Mireia } \\
\text { Castillo }\end{array}$ & $\begin{array}{l}\text { Servei de Neurologia- } \\
\text { Neuroimmunologia, Centre } \\
\text { d'Esclerosi Múltiple de } \\
\text { Catalunya (Cemcat), Vall } \\
\text { d'Hebron Institut de Recerca, } \\
\text { Hospital Universitari Vall } \\
\text { d'Hebron, Departament de } \\
\text { Medicina, Universitat } \\
\text { Autònoma de Barcelona, Spain }\end{array}$ & $\begin{array}{l}\text { Major role in the acquisition } \\
\text { of data }\end{array}$ \\
\hline
\end{tabular}

Appendix (continued)

\begin{tabular}{lll}
\hline Name & Location & Contribution \\
\hline $\begin{array}{l}\text { Mercè } \\
\text { Bonastre }\end{array}$ & $\begin{array}{l}\text { Servei de Neurologia- } \\
\text { Neuroimmunologia, Centre } \\
\text { d'Esclerosi Múltiple de } \\
\text { Catalunya (Cemcat), Vall }\end{array}$ & $\begin{array}{l}\text { Major role in the acquisition } \\
\text { of data } \\
\text { d'Hebron Institut de Recerca, }\end{array}$ \\
& Hospital Universitari Vall & \\
& d'Hebron, Departament de & \\
& Medicina, Universitat & \\
& Autònoma de Barcelona, Spain & \\
\hline Mireia & Servei de Neurologia- & Major role in the acquisition \\
Resina Sallés & Neuroimmunologia, Centre & of data \\
& d'Esclerosi Múltiple de & \\
& Catalunya (Cemcat), Vall & \\
& d'Hebron Institut de Recerca, \\
& Hospital Universitari Vall \\
& d'Hebron, Departament de & \\
& Medicina, Universitat \\
& Autònoma de Barcelona, \\
& Spain
\end{tabular}

\begin{tabular}{lll}
\hline $\begin{array}{l}\text { Jordina } \\
\text { Beltran }\end{array}$ & Servei de Neurologia- & Major role in the acquisition \\
Neuroimmunologia, Centre & of data \\
d'Esclerosi Múltiple de & \\
& Catalunya (Cemcat), Vall \\
d'Hebron Institut de Recerca, & Hospital Universitari Vall \\
& d'Hebron, Departament de \\
& Medicina, Universitat \\
& Autònoma de Barcelona, \\
& Spain
\end{tabular}

\begin{tabular}{lll}
\hline $\begin{array}{l}\text { Pere } \\
\text { Carbonell- } \\
\text { Mirabent }\end{array}$ & $\begin{array}{l}\text { Servei de Neurologia- } \\
\text { Neuroimmunologia, Centre } \\
\text { d'Esclerosi Múltiple de }\end{array}$ & $\begin{array}{l}\text { Drafting/revision of the } \\
\text { manuscript for content, } \\
\text { including medical writing for }\end{array}$ \\
& $\begin{array}{l}\text { Catalunya (Cemcat), Vall } \\
\text { content; major role in the }\end{array}$ \\
& $\begin{array}{l}\text { Hospital Universitari Vall } \\
\text { d'Hebron, Departament de }\end{array}$ & $\begin{array}{l}\text { acquisition of data; and } \\
\text { data }\end{array}$ \\
& $\begin{array}{l}\text { Medicina, Universitat } \\
\text { Autònoma de Barcelona, }\end{array}$ \\
& Spain
\end{tabular}

\begin{tabular}{lll}
\hline Marta & Servei de Neurologia- & Major role in the acquisition \\
Rodríguez- & Neuroimmunologia, Centre & of data \\
Barranco & d'Esclerosi Múltiple de & \\
& Catalunya (Cemcat), Vall \\
& d'Hebron Institut de Recerca, \\
& Hospital Universitari Vall \\
& d'Hebron, Departament de \\
& Medicina, Universitat \\
& Autònoma de Barcelona, \\
& Spain
\end{tabular}

\begin{tabular}{|c|c|c|}
\hline $\begin{array}{l}\text { Samuel } \\
\text { López-Maza, } \\
\text { MD }\end{array}$ & $\begin{array}{l}\text { Servei de Neurologia- } \\
\text { Neuroimmunologia, Centre } \\
\text { d'Esclerosi Múltiple de } \\
\text { Catalunya (Cemcat), Vall } \\
\text { d'Hebron Institut de Recerca, } \\
\text { Hospital Universitari Vall } \\
\text { d'Hebron, Departament de } \\
\text { Medicina, Universitat } \\
\text { Autònoma de Barcelona, } \\
\text { Spain }\end{array}$ & $\begin{array}{l}\text { Major role in the acquisition } \\
\text { of data }\end{array}$ \\
\hline $\begin{array}{l}\text { Pedro José } \\
\text { Melgarejo } \\
\text { Otálora, MD }\end{array}$ & $\begin{array}{l}\text { Department of } \\
\text { Neurology, Hospital } \\
\text { General Universitario } \\
\text { Gregorio Marañón, Madrid, } \\
\text { Spain }\end{array}$ & $\begin{array}{l}\text { Major role in the acquisition } \\
\text { of data }\end{array}$ \\
\hline $\begin{array}{l}\text { Mariano } \\
\text { Ruiz-Ortiz, } \\
\text { MD }\end{array}$ & $\begin{array}{l}\text { Department of Neurology, } \\
\text { Hospital Universitario } 12 \text { de } \\
\text { Octubre, Madrid, Spain }\end{array}$ & $\begin{array}{l}\text { Major role in the acquisition } \\
\text { of data }\end{array}$ \\
\hline
\end{tabular}

Continued 
Appendix (continued)

\begin{tabular}{|c|c|c|}
\hline Name & Location & Contribution \\
\hline $\begin{array}{l}\text { Agustin } \\
\text { Pappolla, } \\
\text { MD }\end{array}$ & $\begin{array}{l}\text { Servei de Neurologia- } \\
\text { Neuroimmunologia, Centre } \\
\text { d'Esclerosi Múltiple de } \\
\text { Catalunya (Cemcat), Vall } \\
\text { d'Hebron Institut de Recerca, } \\
\text { Hospital Universitari Vall } \\
\text { d'Hebron, Departament de } \\
\text { Medicina, Universitat } \\
\text { Autònoma de Barcelona, } \\
\text { Spain }\end{array}$ & $\begin{array}{l}\text { Major role in the acquisition } \\
\text { of data }\end{array}$ \\
\hline $\begin{array}{l}\text { Breogán } \\
\text { Rodríguez } \\
\text { Acevedo, MD }\end{array}$ & $\begin{array}{l}\text { Servei de Neurologia- } \\
\text { Neuroimmunologia, Centre } \\
\text { d'Esclerosi Múltiple de } \\
\text { Catalunya (Cemcat), Vall } \\
\text { d'Hebron Institut de Recerca, } \\
\text { Hospital Universitari Vall } \\
\text { d'Hebron, Departament de } \\
\text { Medicina, Universitat } \\
\text { Autònoma de Barcelona, } \\
\text { Spain }\end{array}$ & $\begin{array}{l}\text { Major role in the acquisition } \\
\text { of data }\end{array}$ \\
\hline $\begin{array}{l}\text { Luciana } \\
\text { Midaglia, MD }\end{array}$ & $\begin{array}{l}\text { Servei de Neurologia- } \\
\text { Neuroimmunologia, Centre } \\
\text { d'Esclerosi Múltiple de } \\
\text { Catalunya (Cemcat), Vall } \\
\text { d'Hebron Institut de Recerca, } \\
\text { Hospital Universitari Vall } \\
\text { d'Hebron, Departament de } \\
\text { Medicina, Universitat } \\
\text { Autònoma de Barcelona, } \\
\text { Spain }\end{array}$ & $\begin{array}{l}\text { Major role in the acquisition } \\
\text { of data }\end{array}$ \\
\hline
\end{tabular}

Angela Vidal- Servei de Neurologia-

Major role in the acquisition d'Esclerosi Múltiple de Catalunya (Cemcat), Vall d'Hebron Institut de Recerca, Hospital Universitari Vall d'Hebron, Departament de Medicina, Universitat Autònoma de Barcelona, Spain

\begin{tabular}{lll}
\hline Alvaro Cobo- & Servei de Neurologia- & Major role in the acquisition \\
Calvo, MD, & Neuroimmunologia, Centre & of data \\
PhD & d'Esclerosi Múltiple de & \\
& Catalunya (Cemcat), Vall \\
d'Hebron Institut de Recerca, & \\
& Hospital Universitari Vall \\
d'Hebron, Departament de & \\
& Medicina, Universitat \\
& Autònoma de Barcelona, \\
& Spain
\end{tabular}

Carmen Tur, Servei de NeurologiaMD, PhD Neuroimmunologia, Centre of data d'Esclerosi Múltiple de Catalunya (Cemcat), Vall d'Hebron Institut de Recerca, Hospital Universitari Vall d'Hebron, Departament de Medicina, Universitat Autònoma de Barcelona, Spain

\begin{tabular}{lll}
\hline Ingrid Galán, & Servei de Neurologia- & Major role in the acquisition \\
MD & Neuroimmunologia, Centre \\
d'Esclerosi Múltiple de & of data \\
Catalunya (Cemcat), Vall & \\
d'Hebron Institut de Recerca, & Hospital Universitari Vall \\
d'Hebron, Departament de & Medicina, Universitat \\
Autònoma de Barcelona, \\
Spain
\end{tabular}

Appendix (continued)

\begin{tabular}{|c|c|c|}
\hline Name & Location & Contribution \\
\hline $\begin{array}{l}\text { Joaquín } \\
\text { Castilló, MD, } \\
\text { PhD }\end{array}$ & $\begin{array}{l}\text { Servei de Neurologia- } \\
\text { Neuroimmunologia, Centre } \\
\text { d'Esclerosi Múltiple de } \\
\text { Catalunya (Cemcat), Vall } \\
\text { d'Hebron Institut de Recerca, } \\
\text { Hospital Universitari Vall } \\
\text { d'Hebron, Departament de } \\
\text { Medicina, Universitat } \\
\text { Autònoma de Barcelona, } \\
\text { Spain }\end{array}$ & $\begin{array}{l}\text { Major role in the acquisition } \\
\text { of data }\end{array}$ \\
\hline $\begin{array}{l}\text { Jordi Río, } \\
\text { MD, PhD }\end{array}$ & $\begin{array}{l}\text { Servei de Neurologia- } \\
\text { Neuroimmunologia, Centre } \\
\text { d'Esclerosi Múltiple de } \\
\text { Catalunya (Cemcat), Vall } \\
\text { d'Hebron Institut de Recerca, } \\
\text { Hospital Universitari Vall } \\
\text { d'Hebron, Departament de } \\
\text { Medicina, Universitat } \\
\text { Autònoma de Barcelona, } \\
\text { Spain }\end{array}$ & $\begin{array}{l}\text { Major role in the acquisition } \\
\text { of data }\end{array}$ \\
\hline $\begin{array}{l}\text { Carmen } \\
\text { Espejo, MD, } \\
\text { PhD }\end{array}$ & $\begin{array}{l}\text { Servei de Neurologia- } \\
\text { Neuroimmunologia, Centre } \\
\text { d'Esclerosi Múltiple de } \\
\text { Catalunya (Cemcat), Vall } \\
\text { d'Hebron Institut de Recerca, } \\
\text { Hospital Universitari Vall } \\
\text { d'Hebron, Departament de } \\
\text { Medicina, Universitat } \\
\text { Autònoma de Barcelona, } \\
\text { Spain }\end{array}$ & $\begin{array}{l}\text { Drafting/revision of the } \\
\text { manuscript for content, } \\
\text { including medical writing for } \\
\text { content; study concept or } \\
\text { design; and analysis or } \\
\text { interpretation of data }\end{array}$ \\
\hline $\begin{array}{l}\text { Manuel } \\
\text { Comabella, } \\
\text { MD, PhD }\end{array}$ & $\begin{array}{l}\text { Servei de Neurologia- } \\
\text { Neuroimmunologia, Centre } \\
\text { d'Esclerosi Múltiple de } \\
\text { Catalunya (Cemcat), Vall } \\
\text { d'Hebron Institut de Recerca, } \\
\text { Hospital Universitari Vall } \\
\text { d'Hebron, Departament de } \\
\text { Medicina, Universitat } \\
\text { Autònoma de Barcelona, } \\
\text { Spain }\end{array}$ & $\begin{array}{l}\text { Drafting/revision of the } \\
\text { manuscript for content, } \\
\text { including medical writing for } \\
\text { content, and analysis or } \\
\text { interpretation of data }\end{array}$ \\
\hline
\end{tabular}

\begin{tabular}{|c|c|c|}
\hline $\begin{array}{l}\text { Carlos Nos, } \\
\text { MD }\end{array}$ & $\begin{array}{l}\text { Servei de Neurologia- } \\
\text { Neuroimmunologia, Centre } \\
\text { d'Esclerosi Múltiple de } \\
\text { Catalunya (Cemcat), Vall } \\
\text { d'Hebron Institut de Recerca, } \\
\text { Hospital Universitari Vall } \\
\text { d'Hebron, Departament de } \\
\text { Medicina, Universitat } \\
\text { Autònoma de Barcelona, } \\
\text { Spain }\end{array}$ & $\begin{array}{l}\text { Major role in the acquisition } \\
\text { of data }\end{array}$ \\
\hline $\begin{array}{l}\text { Jaume } \\
\text { Sastre- } \\
\text { Garriga, MD, } \\
\text { PhD }\end{array}$ & $\begin{array}{l}\text { Servei de Neurologia- } \\
\text { Neuroimmunologia, Centre } \\
\text { d'Esclerosi Múltiple de } \\
\text { Catalunya (Cemcat), Vall } \\
\text { d'Hebron Institut de Recerca, } \\
\text { Hospital Universitari Vall } \\
\text { d'Hebron, Departament de } \\
\text { Medicina, Universitat } \\
\text { Autònoma de Barcelona, } \\
\text { Spain }\end{array}$ & $\begin{array}{l}\text { Drafting/revision of the } \\
\text { manuscript for content, } \\
\text { including medical writing for } \\
\text { content; major role in the } \\
\text { acquisition of data; study } \\
\text { concept or design; and } \\
\text { analysis or interpretation of } \\
\text { data }\end{array}$ \\
\hline $\begin{array}{l}\text { Mar Tintore, } \\
\text { MD, PhD }\end{array}$ & $\begin{array}{l}\text { Servei de Neurologia- } \\
\text { Neuroimmunologia, Centre } \\
\text { d'Esclerosi Múltiple de } \\
\text { Catalunya (Cemcat), Vall } \\
\text { d'Hebron Institut de Recerca, } \\
\text { Hospital Universitari Vall } \\
\text { d'Hebron, Departament de } \\
\text { Medicina, Universitat } \\
\text { Autònoma de Barcelona, } \\
\text { Spain }\end{array}$ & $\begin{array}{l}\text { Drafting/revision of the } \\
\text { manuscript for content, } \\
\text { including medical writing for } \\
\text { content; major role in the } \\
\text { acquisition of data; study } \\
\text { concept or design; analysis } \\
\text { or interpretation of data; } \\
\text { and additional } \\
\text { contributions: study } \\
\text { supervision }\end{array}$ \\
\hline
\end{tabular}


Appendix (continued)

\begin{tabular}{|c|c|c|}
\hline Name & Location & Contribution \\
\hline $\begin{array}{l}\text { Xavier } \\
\text { Montalban, } \\
\text { MD, PhD }\end{array}$ & $\begin{array}{l}\text { Servei de Neurologia- } \\
\text { Neuroimmunologia, Centre } \\
\text { d'Esclerosi Múltiple de } \\
\text { Catalunya (Cemcat), Vall } \\
\text { d'Hebron Institut de Recerca, } \\
\text { Hospital Universitari Vall } \\
\text { d'Hebron, Departament de } \\
\text { Medicina, Universitat } \\
\text { Autònoma de Barcelona, } \\
\text { Spain }\end{array}$ & $\begin{array}{l}\text { Drafting/revision of the } \\
\text { manuscript for content, } \\
\text { including medical writing for } \\
\text { content; major role in the } \\
\text { acquisition of data; study } \\
\text { concept or design; analysis } \\
\text { or interpretation of data; } \\
\text { and additional } \\
\text { contributions: study } \\
\text { supervision }\end{array}$ \\
\hline
\end{tabular}

\section{References}

1. COVID-19 Map. Johns Hopkins Coronavirus Resource Center; 2020:1. Accessed November 4, 2021. coronavirus.jhu.edu/map.html.

2. Sormani MP, De Rossi N, Schiavetti I, et al. Disease-modifying therapies and coronavirus disease 2019 severity in multiple sclerosis. Ann Neurol. 2021;89(4):780-789. doi:10.1002/ANA.26028.

3. Salter A, Fox RJ, Newsome SD, et al. Outcomes and risk factors associated with SARSCoV-2 infection in a North American Registry of Patients with Multiple Sclerosis. JAMA Neurol. 2021;78(6):699-708. doi:10.1001/jamaneurol.2021.0688.

4. Simpson-Yap S, De Brouwer E, Kalincik T, et al. Associations of disease-modifying therapies with COVID-19 severity in multiple sclerosis. Neurology. 2021;97(19): e1870-e1885. doi:10.1212/WNL.0000000000012753.

5. Louapre C, Collongues N, Stankoff B, et al. Clinical characteristics and outcomes in patients with coronavirus disease 2019 and multiple sclerosis. JAMA Neurol. 2020; 77(9):1079-1088. doi:10.1001/jamaneurol.2020.2581.

6. Zabalza A, Cárdenas-Robledo S, Tagliani P, et al. COVID-19 in MS patients: susceptibility, severity risk factors and serological response. Eur J Neurol. 2021;28(10): 3384-3385. doi:10.1111/ene.14690.

7. van Kempen ZLE, Strijbis EMM, Al MMCT, et al. SARS-CoV-2 antibodies in adult patients with multiple sclerosis in the Amsterdam MS Cohort. JAMA Neurol. 2021; 78(7):880-882. doi:10.1001/jamaneurol.2021.1364.

8. Sormani MP, Schiavetti I, Landi D, et al. SARS-CoV-2 serology after COVID-19 in multiple sclerosis: an international cohort study. Mult Scler J. 2021;2021: 135245852110353. doi:10.1177/13524585211035318.

9. Louapre C, Ibrahim M, Maillart E, et al. Anti-CD20 therapies decrease humoral immune response to sars-cov- 2 in patients with multiple sclerosis or neuromyelitis optica spectrum disorders. J Neurol Neurosurg Psychiatry. 2022;93(1):24-31. doi:10.1136/jnnp-2021-326904.

10. Achiron A, Mandel M, Dreyer-Alster S, et al. Humoral immune response to COVID19 mRNA vaccine in patients with multiple sclerosis treated with high-efficacy diseasemodifying therapies. Ther Adv Neurol Disord. 2021;14:17562864211012835. doi: $10.1177 / 17562864211012835$.

11. Sormani MP, Inglese M, Schiavetti I, et al. Effect of SARS-CoV-2 mRNA vaccination in MS patients treated with disease modifying therapies. EBioMedicine. 2021;72: 103581. doi:10.1016/J.EBIOM.2021.103581.

12. Apostolidis SA, Kakara M, Painter MM, et al. Cellular and humoral immune responses following SARS-CoV-2 mRNA vaccination in patients with multiple sclerosis on antiCD20 therapy. Nat Med. 2021;27(11):1990-2001. doi:10.1038/s41591-021-01507-2.

13. Brill L, Rechtman A, Zveik O, et al. Humoral and T-cell response to SARS-CoV-2 vaccination in patients with multiple sclerosis treated with ocrelizumab. JAMA Neurol. 2021;78(12):1510-1514:. doi:10.1001/JAMANEUROL.2021.3599.

14. Case definition for coronavirus disease 2019 (COVID-19), as of 3 December 2020. Accessed July 4, 2021. ecdc.europa.eu/en/covid-19/surveillance/case-definition.
15. Radbruch A, Chang HD. A long-term perspective on immunity to COVID. Nature 2021;595(7867):359-360. doi:10.1038/d41586-021-01557-z.

16. Post N, Eddy D, Huntley C, et al. Antibody response to SARS-CoV-2 infection in humans: a systematic review. PLoS One. 2020;15(12):e0244126. doi:10.1371/ journal.pone.0244126.

17. Bonelli F, Sarasini A, Zierold C, et al. Clinical and analytical performance of an automated serological test that identifies S1/S2-neutralizing IgG in COVID-19 patients semiquantitatively. J Clin Microbiol. 2020;58(9):e01224-20. doi:10.1128/ JCM.01224-20.

18. Grant OC, Montgomery D, Ito K, Woods RJ. Analysis of the SARS-CoV-2 spike protein glycan shield reveals implications for immune recognition. Sci Rep. 2020; 10(1):14991. doi:10.1038/s41598-020-71748-7.

19. Wu J, Liang B, Chen C, et al. SARS-CoV-2 infection induces sustained humoral immune responses in convalescent patients following symptomatic COVID-19. Nat Commun. 2021;12(1):1813. doi:10.1038/s41467-021-22034-1.

20. Baker D, Roberts CAK, Pryce G, et al. COVID-19 vaccine-readiness for anti-CD20depleting therapy in autoimmune diseases. Clin Exp Immunol. 2020;202(2):149-161. doi: $10.1111 /$ cei.13495

21. Bigaut K, Kremer L, Fabacher T, et al. Impact of disease-modifying treatments of multiple sclerosis on anti-SARS-CoV-2 antibodies: an observational study. Neurol Neuroimmunol Neuroinflamm. 2021;8(5):e1055. doi:10.1212/NXI.0000000000001055.

22. Takahashi T, Ellingson MK, Wong $P$, et al. Sex differences in immune responses that underlie COVID-19 disease outcomes. Nature. 2020;588(7837):315-320. doi: 10.1038/s41586-020-2700-3.

23. Kutsuna S, Asai Y, Matsunaga A, et al. Factors associated with anti-SARS-CoV-2 IgC antibody production in patients convalescing from COVID-19. J Infect Chemother. 2021;27(6):808-813. doi:10.1016/j.jiac.2021.01.006.

24. Mathew D, Giles JR, Baxter AE, et al. Deep immune profiling of COVID-19 patients reveals distinct immunotypes with therapeutic implications. Science. 2020;369(6508): eabc8511. doi:10.1126/SCIENCE.ABC8511.

25. Murugesan K, Jagannathan $\mathrm{P}$, Pham TD, et al. Interferon-gamma release assay for accurate detection of SARS-CoV-2 T cell response. Clin Infect Dis. 2020;73(9): e3130-e3132. doi:10.1093/cid/ciaa1537.

26. Sekine $\mathrm{T}$, Perez-Potti A, Rivera-Ballesteros $\mathrm{O}$, et al. Robust $\mathrm{T}$ cell immunity in convalescent individuals with asymptomatic or mild COVID-19. Cell. 2020;183(1): 158-168.e14. doi:10.1016/j.cell.2020.08.017.

27. Wijnands JMA, Kingwell E, Zhu F, et al. Infection-related health care utilization among people with and without multiple sclerosis. Mult Scler. 2017;23(11): 1506-1516. doi:10.1177/1352458516681198.

28. Zhang J, Lin H, Ye B, et al. One-year sustained cellular and humoral immunities of COVID-19 convalescents. Clin Infect Dis. 2021;2021:ciab884. doi:10.1093/cid/ciab884

29. Iannetta M, Landi D, Cola G, et al. T-cell responses to SARS-CoV-2 in multiple sclerosis patients treated with ocrelizumab healed from COVID-19 with absent or low anti-spike antibody titers. Mult Scler Relat Disord. 2021;55:103157. doi:10.1016/j.msard.2021.103157.

30. Bange EM, Han NA, Wileyto P, et al. CD8+ T cells contribute to survival in patients with COVID-19 and hematologic cancer. Nat Med. 2021;27(7):1280-1289. doi: 10.1038/s41591-021-01386-7.

31. Dema M, Eixarch H, Villar LM, Montalban X, Espejo C. Immunosenescence in multiple sclerosis: the identification of new therapeutic targets. Autoimmun Rev. 2021, 20(9):102893. doi:10.1016/J.AUTREV.2021.102893.

32. Dan JM, Mateus J, Kato Y, et al. Immunological memory to SARS-CoV-2 assessed for up to 8 months after infection. Science. 2021;371(6529):eabf4063. doi:10.1126/science.abf 4063 .

33. Turner JS, Kim W, Kalaidina E, et al. SARS-CoV-2 infection induces long-lived bone marrow plasma cells in humans. Nature. 2021;595(7867):421-425. doi:10.1038/ s41586-021-03647-4.

34. Yao L, Wang G-L, Shen Y, et al. Persistence of antibody and cellular immune responses in coronavirus disease 2019 patients over nine months after infection. J Infect Dis. 2021;224(4):586-594. doi:10.1093/INFDIS/JIAB255.

35. Chia WN, Zhu F, Ong SWX, et al. Dynamics of SARS-CoV-2 neutralising antibody responses and duration of immunity: a longitudinal study. Lancet Microbe. 2021;2(6) e240-e249. doi:10.1016/S2666-5247(21)00025-2. 


\title{
Neurology \\ Neuroimmunology \& Neuroinflammation
}

\author{
Humoral and Cellular Responses to SARS-CoV-2 in Convalescent COVID-19 Patients \\ With Multiple Sclerosis \\ Ana Zabalza, Georgina Arrambide, Paula Tagliani, et al. \\ Neurol Neuroimmunol Neuroinflamm 2022;9; \\ DOI 10.1212/NXI.0000000000001143
}

This information is current as of February 1, 2022

\begin{abstract}
Updated Information \&
Services

References

Citations

Permissions \& Licensing

Reprints

including high resolution figures, can be found at:

http://nn.neurology.org/content/9/2/e1143.full.html

This article cites 33 articles, 5 of which you can access for free at: http://nn.neurology.org/content/9/2/e1143.full.html\#\#ref-list-1

This article has been cited by 2 HighWire-hosted articles:

http://nn.neurology.org/content/9/2/e1143.full.html\#\#otherarticles

Information about reproducing this article in parts (figures,tables) or in its entirety can be found online at:

http://nn.neurology.org/misc/about.xhtml\#permissions

Information about ordering reprints can be found online: http://nn.neurology.org/misc/addir.xhtml\#reprintsus
\end{abstract}

Neurol Neuroimmunol Neuroinflamm is an official journal of the American Academy of Neurology.

Published since April 2014, it is an open-access, online-only, continuous publication journal. Copyright

Copyright $\odot 2022$ The Author(s). Published by Wolters Kluwer Health, Inc. on behalf of the American

Academy of Neurology.. All rights reserved. Online ISSN: 2332-7812.

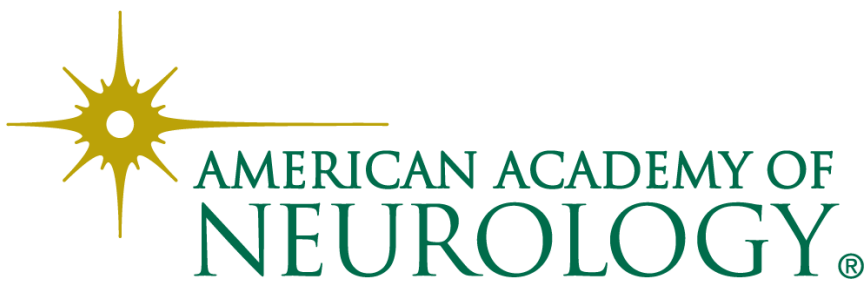

